\title{
FAKTOR YANG BERPENGARUH TERHADAP KEPATUHAN MASYARAKAT PADA PROTOKOL KESEHATAN DALAM MENCEGAH PENYEBARAN COVID-19
}

\author{
(FACTORS AFFECTING COMMUNITY COMPLIANCE WITH HEALTH PROTOCOLS IN \\ PREVENTING THE SPREAD OF COVID-19)
}

\author{
Riyadi $^{1}$, Putri Larasaty ${ }^{2}$ \\ Direktorat Analisis dan Pengembangan Statistik, BPS ${ }^{1}$ \\ Direktorat Analisis dan Pengembangan Statistik, BPS ${ }^{2}$ \\ Jalan dr. Sutomo No. 6-8 Jakarta \\ E-mail: riyadi@bps.go.id
}

\begin{abstract}
ABSTRAK
Pandemi Covid-19 merupakan salah satu kejadian yang dihadapi oleh berbagai negara di dunia dalam bidang kesehatan. Meluasnya penyebaran virus ini menjadi isu yang sangat krusial untuk segera dihentikan. Berbagai macam kebijakan telah dilakukan oleh pemerintah demi mengentikan penyebaran pandemi ini. Namun, di sisi lain masyarakat dituntut untuk mematuhi protokol kesehatan dalam upayanya menghentikan penyebaran Covid -19 supaya tidak meluas. Penelitian ini bertujuan untuk menganalisis tingkat kepatuhan masyarakat dalam penerapan protokol kesehatan dalam kehidupan sehari-harinya, serta untuk mengetahui faktor sosial demografi yang berpengaruh terhadap kepatuhan penerapan protokol kesehatan di dalam masyarakat di Indonesia. Data yang digunakan dalam penelitian ini berasal dari Survei Sosial Demografi Dampak Covid -19 tahun 2020 dari BPS. Analisis ini menggunakan analisis deskriptif dan analisis regresi. Hasil empiris menunjukkan rata-rata indeks kepatuhan responden laki-laki lebih rendah dibandingkan responden perempuan, serta terdapat kecenderungan bahwa kaum muda lebih tidak acuh terhadap penerapan protokol kesehatan dengan rata-rata skor kepatuhan yang relatif lebih rendah dibandingkan dengan kaum yang lebih tua. Selain itu, karakteristik sosial demografi yang berpengaruh terhadap tingkat kepatuhan masyarakat dalam penerapan protokol kesehatan yaitu status reaksi responden, persepsi keefektifan isolasi mandiri, tingkat kekhawatiran tentang berita Covid -19 , tingkat kekhawatiran tentang bepergian ke luar rumah, jenis kelamin, tingkat pendidikan, status pernikahan, status kesehatan, dan usia.
\end{abstract}

Kata kunci: covid-19, kepatuhan masyarakat, protokol kesehatan, sosial demografi

\section{ABSTRACT}

The Covid-19 pandemic is one of the events threatening all around the world particularly in health sector. The widespread of this virus causes the most crucial issue to stop it immediately. Various kinds of policies have been made by the government to end the spread. However, on the other hand, the community is critically required to comply with health protocols as a serious effort to stop it. This study aims to analyze the level of community compliance in implementing health protocols in their daily lives, as well as to determine the sociodemographic factors that affect compliance with health protocols in society in Indonesia. The data used in this study is derived from the 2020 Social Demographic Impact of Covid-19 Survey from BPS. This analysis uses descriptive and regression analysis. The empirical results show that the average adherence index of male respondents is lower than that of female respondents, and there is a tendency that young people are more disobeying about health protocols with a relatively lower average adherence score compared to the older people. In addition, the socio-demographic characteristics that affect the level of community compliance with health protocols are respondent reaction status, perceptions of the effectiveness of independent isolation, level of concern about Covid-19 news, level of concern about traveling outside the home, gender, education level, marital status, health status, and age.

Keywords: covid-19, community compliance, health protocols, social demographics 


\section{PENDAHULUAN}

Pandemi Corona Virus Disease 2019 (Covid-19) untuk pertama kalinya muncul di Kota Wuhan, China pada Desember 2019. Kemudian, wabah ini menyebar sangat cepat ke beberapa negara di dunia, tak terkecuali Indonesia. Wabah yang disebabkan oleh Novel Coronavirus (NCoV) ini pun telah ditetapkan sebagai pandemi global oleh World Health Organization (WHO). Di Indonesia, pandemi Covid-19 telah ditetapkan sebagai jenis penyakit yang menimbulkan Kedaruratan Kesehatan Masyarakat pada 31 Maret 2020, sesuai dalam Keputusan Presiden Nomor 11 Tahun 2020 tentang Penetapan Kedaruratan Kesehatan Masyarakat Corona Virus Disease (COVID-19). Dengan adanya penetapan tersebut, upaya penanggulangan wajib dilakukan sesuai dengan peraturan perundang-undangan dalam masa tanggap darurat penanganan Covid-19.

Untuk mengurangi dan mencegah transmisi virus ini, pemerintah telah mewajibkan masyarakatnya untuk menjaga protokol kesehatan. Satuan Tugas Penangangan Covid-19 terus berupaya dalam menyampaikan pesan kepada seluruh masyarakat untuk mengurangi risiko penularan virus Covid-19, seperti berdiam diri di rumah, menggunakan masker, sering mencuci tangan menggunakan sabun dan air mengalir, menjaga jarak fisik (physical distancing), dan tidak menyentuh wajah, mata, hidung, dan mulut. Namun, penerapan perilaku sosial yang baru pada masyarakat tidaklah mudah dan masih ada sebagian orang masih belum taat dalam penerapan kebiasaan baru ini. Kemenkes juga menerbitkan buku panduan yang dapat digunakan dalam rangka pengendalian Covid-19. Kemenkes (2020) menyatakan bahwa panduan ini diterbitkan dengan tujuan untuk melaksanakan pencegahan dan pengendalian Covid-19 di Indonesia. Tujuan khususnya untuk memahami strategi dan indikator penanggulangan, melaksanakan surveilans epidemiologi, melaksanakan diagnosis laboratorium, melaksanakan manajemen klinis, melaksanakan pencegahan dan pengendalian penularan, melaksanakan komunikasi risiko dan pemberdayaan masyarakat, melaksanakan penyediaan sumber daya, dan melaksanakan pelayanan kesehatan esensial.

Kebiasaan baru dalam menjaga kesehatan ini dapat dijelaskan dengan beberapa teori mengenai perilaku. Theory of Planned Behaviour oleh Ajzen (2005) menjelaskan bahwa perilaku individu didorong niat yang dipengaruhi oleh tiga faktor yaitu Behavioral Beliefs, Normative Beliefs, dan Control Beliefs. Selain itu, faktor pendukung seperti faktor personal, sosial, dan informasi menjadi faktor yang memengaruhi perilaku individu. Perilaku mencegah penyakit juga dijelaskan dalam Protection Motivation Theory yang menyatakan bahwa informasi kesehatan yang bersifat peringatan dapat merubah sikap perilaku individu. Teori yang dikembangkan oleh Rogers \& Prentice-Dunn, (1997) ini menjelaskan bahwa dari informasi yang diperoleh, motivasi untuk melindungi diri bergantung pada penilaian terhadap ancaman (threat appraisa) dan strategi dalam menghadapi ancaman (coping appraisa).

Bashirian, dkk. (2020) telah melakukan penelitian perilaku pegawai di Rumah Sakit Iran dalam pencegahan penularan Covid-19. Hasilnya menyatakan bahwa persepsi terhadap ancaman (tingkat keparahan) dan keefektifan anjuran yang direkomendasikan memberikan pengaruh perilaku petugas/tenaga medis dalam pencegahan penularan virus ini. Selain itu, karakteristik demografis juga memberikan persepsi ancaman yang berbeda, dimana wanita memiliki penilaian ancaman yang lebih tinggi. Berdasarkan penelitian tersebut, Bashirian, dkk. (2020) menekankan pentingnya informasi untuk meningkatkan persepsi efektifitas perilaku protektif terhadap Covid-19. Penelitian yang dilakukan oleh Prasetyo, dkk. (2020) juga menunjukkan bahwa pemahaman tentang Covid-19 memiliki pengaruh langsung yang signifikan terhadap persepsi ancaman dan tingkat keparahan. Selanjutnya, ancaman dan keparahan yang dirasakan memiliki efek yang siginifikan terhadap niat berperilaku meski secara tidak langsung. Kemudian, niat tersebut secara langsung berpengaruh secara signifikan pada perilaku seseorang.

Yanti, dkk. (2020) juga menyatakan penerapan perilaku kesehatan erat kaitannya dengan pengetahuan dan respons atau sikap seseorang. Penelitian yang menganalisis perilaku taat pada kebijakan social distancing sebagai upaya pencegahan penularan Covid-9 di Indonesia tersebut menunjukkan bahwa tingkat pendidikan dan pekerjaan memengaruhi sikap positi dalam penerapan social distancing. Pengetahuan yang baik dalam efektivitas social distancing dan sikap atau respons yang positif akan meningkatkan niat untuk berperilaku sesuai rekomendasi pemerintah.

Penelitian mengenai perilaku dalam pencegahan penularan Covid-19 juga telah dilakukan oleh Triyanto \& Kusumawardani (2020), yang menyatakan bahwa pengetahuan yang minim mengenai 46 
Covid-19 memengaruhi perilaku seseorang. Pengetahuan yang baik mengenai pencegahan penularan Covid-19 akan meningkatkan tingkat kewaspadaan dan pemahaman mengenai pentingnya dalam mencegah penularan penyakit ini. Pengetahuan atau informasi yang diperoleh ini dipengaruhi oleh tingkat pendidikan mayarakat dan karakteristik wilayah (perkotaan atau perdesaan). Penelitian yang dilakukan di Prancis oleh Raude, dkk. (2020) menjelaskan bahwa terdapat perbedaan respons perilaku terhadap penularan Covid-19, dimana laki-laki dan usia muda lebih cenderung untuk tidak mematuhi anjuran pemerintah. Namun demikian, perilaku tersebut masih dapat diubah dengan menekankan norma-norma positif untuk mempromosikan perilaku kesehatan yang adaptif. Berdasarkan literatur-literatur tersebut, perbedaan karakteristik dan penilaian masyarakat menentukan perilaku dalam menjaga kesehatan atau penularan penyakit. Persepsi masyarakat yang tidak termotivasi untuk menjaga diri ini akan berdampak pada penularan Covid-19 yang semakin meluas.

Penelitian ini bertujuan untuk mengetahui tingkat kepatuhan masyarakat terhadap protokol kesehatan di masa pandemi Covid-19 dalam rangka pencegahan penyebaran Covid-19. Selain itu juga ingin melihat pengaruh faktor karakteristik sosial demografi masyarakat terhadap tingkat kepatuhan masyarakat dalam penerapan protokol kesehatan. Penelitian ini diharapakan dapat memberikan bahan masukan bagi pemangku kebijakan dalam menerapkan aturan pengendalian penyebaran Covid-19 dan memberikan pengawasan terhadap penerapan protokol kesehatan pada masyarakat.

\section{METODE}

\section{Data dan Sumber Data}

Penelitian ini menggunakan data hasil Survei Sosial Demografi Dampak Covid-19 yang dilaksanakan oleh BPS pada Bulan April 2020 secara online (BPS, 2020). Jumlah observasi yang digunakan dalam penelitian ini sebesar 87.379 responden. Variabel penelitian yang digunakan dalam penelitian ini terbatas pada variabel yang tersedia pada kuesioner atau pertanyaan di dalam survei yaitu skor tingkat kepatuhan masyarakat dalam penerapan protokol kesehatan, status reaksi responden menyikapi kondisi wabah Covid-19, persepsi keefektifan tindakan isolasi diri atau karantina mandiri yang dilakukannya dapat memperlambat penyebaran Covid-19, tingkat kekhawatiran tentang berita Covid-19, tingkat kekhawatiran ketika bepergian ke luar rumah, jenis kelamin, tingkat pendidikan, status pernikahan, status kesehatan, usia, status bekerja, dan jumlah anggota rumah.

\section{Teknik Analisis Data}

Metode analisis yang digunakan dalam penelitian ini yaitu analisis deskriptif untuk melihat sejauh mana tingkat kepatuhan masyarakat dalam menerapkan protokol kesehatan dengan menggunakan rata-rata skor tingkat kepatuhan. Selain itu, penelitian ini juga menggunakan analisis inferensia. Analisis inferensia yang digunakan adalah analisis regresi linear berganda. Dalam analisis regresi, terdapat beberapa asumsi klasik yang perlu dipenuhi, antara lain

1. Normalitas

Pengertian dari asumsi klasik normalitas adalah setiap residual mengikuti distribusi normal Berdasarkan Gujarati \& Porter (2009), terdapat beberapa cara untuk menguji normalitas dari residual, antara lain: histogram dari residual, Normal Probability Plot (NPP), dan uji JarqueBera. Pada asumsi ini juga dapat mengggunakan Teorema Limit Sentral (Central Limit Theorem) yang menyatakan bahwa jumlah variabel acak independen yang berjumlah besar cenderung ke arah distribusi normal.

2. Nonmultikolinearitas

Multikolinearitas mengindikasikan adanya hubungan liniear antar beberapa atau semua variabel bebas (independent variables) dalam sebuah model regresi. Gujarati \& Porter (2009) menyatakan bahwa asumsi multikolinearitas yang tidak terpenuhi akan menghasilkan 
estimator dengan presisi yang rendah, pengujian parsial yang tidak signifikan, serta estimator dan standar eror yang sensitif terhadap perubahan data yang kecil.

3. Homoskedastisitas

Pengertian dari asumsi ini adalah varians/persebaran yang sama. Asumsi homoskedastisitas baik yang terpenuhi maupun tidak akan menghasilkan estimator yang linier, unbiased, dan konsisten. Akan tetapi, disaat asumsi ini tidak terpenuhi, estimator yang diperoleh tidak memenuhi sifat varias minimum/tidak efisien atau tidak BLUE (Best Linear Unbiased Estimator).

4. Nonautokorelasi

Autokorelasi adalah korelasi antar observasi yang lebih banyak ditemukan pada data antar waktu atau time series (Greene, 2012). Asumsi nonautokorelasi yang tidak terpenuhi akan tetap menghasilkan estimator yang bersifat linier dan unbiased. Akan tetapi, estimator tersebut tidak bersifat BLUE karena tidak memiliki varians minimum.

Tabel 1. Deskripsi Variabel yang Digunakan dalam Penelitian.

\begin{tabular}{|c|c|}
\hline Variabel & Keterangan \\
\hline $\begin{array}{l}\text { Skor tingkat kepatuhan masyarakat } \\
\text { dalam penerapan protokol } \\
\text { kesehatan }\end{array}$ & $\begin{array}{l}\text { Skor dihitung dari rata-rata skor yang diisi oleh responden dari } 13 \\
\text { pertanyaan (pengetahuan tentang kebijakan physical distancing } \\
\text { atau menjaga jarak; perilaku penerapan physical distancing atau } \\
\text { menjaga jarak; memakai masker; memakai sarung tangan; } \\
\text { menggunakan hand sanitizer/disinfektan; mencuci tangan selama } \\
20 \text { detik dengan sabun; menghindari menyentuh wajah; } \\
\text { menghindari berjabat tangan; menghindari pertemuan atau } \\
\text { berdiri dalam antrian panjang; menghindari menyentuh } \\
\text { benda/permukaan benda di area publik; menghindari naik } \\
\text { transportasi umum (termasuk transportasi online); saya menjaga } \\
\text { jarak setidaknya dua meter dari orang lain ketika di luar rumah; } \\
\text { dan jika saya menunjukkan gejala penyakit, saya akan segera } \\
\text { memberi tahu orang-orang di sekitar saya) }\end{array}$ \\
\hline $\begin{array}{l}\text { Status reaksi responden menyikapi } \\
\text { kondisi wabah Covid-19 }\end{array}$ & $\begin{array}{l}\text { Bernilai } 0 \text { jika reaksi tidak/kurang peduli, bernilai } 1 \text { jika reaksi } \\
\text { tepat, agak/terlalu berlebihan }\end{array}$ \\
\hline $\begin{array}{l}\text { Persepsi keefektifan tindakan isolasi } \\
\text { diri atau karantina mandiri yang } \\
\text { dilakukannya dapat memperlambat } \\
\text { penyebaran Covid-19 }\end{array}$ & $\begin{array}{l}\text { Bernilai } 0 \text { jika persepsi tidak/kurang efektif dan biasa saja, bernilai } \\
1 \text { jika persepsi cukup dan sangat efektif }\end{array}$ \\
\hline $\begin{array}{l}\text { Tingkat kekhawatiran tentang berita } \\
\text { Covid-19 }\end{array}$ & $\begin{array}{l}\text { Bernilai } 0 \text { jika skor kekhawatiran } 1 \text { atau 2, bernilai } 1 \text { jika skor } \\
\text { kekhawatiran 3, } 4 \text { atau } 5\end{array}$ \\
\hline $\begin{array}{l}\text { Tingkat kekhawatiran ketika } \\
\text { bepergian ke luar rumah }\end{array}$ & $\begin{array}{l}\text { Bernilai } 0 \text { jika skor kekhawatiran } 1 \text { atau 2, bernilai } 1 \text { jika skor } \\
\text { kekhawatiran 3, } 4 \text { atau } 5\end{array}$ \\
\hline Jenis kelamin & Bernilai 0 jika responden perempuan, bernilai 1 jika laki-laki \\
\hline Tingkat pendidikan & $\begin{array}{l}\text { Bernilai } 0 \text { jika tingkat pendidikan SMP ke bawah, bernilai } 1 \text { jika } \\
\text { tingkat pendidikan SMA ke atas }\end{array}$ \\
\hline Status pernikahan & $\begin{array}{l}\text { Bernilai } 0 \text { jika belum menikah, cerai hidup/mati, bernilai } 1 \text { jika } \\
\text { menikah }\end{array}$ \\
\hline Status kesehatan & $\begin{array}{l}\text { Bernilai } 0 \text { jika status kesehatan kurang sehat/sakit, bernilai } 1 \text { jika } \\
\text { sehat }\end{array}$ \\
\hline Usia & Usia responden \\
\hline Status bekerja & $\begin{array}{l}\text { Bernilai } 0 \text { jika tidak bekerja/sementara dirumahkan dan PHK, } \\
\text { bernilai } 1 \text { jika statusnya bekerja }\end{array}$ \\
\hline Jumlah anggota rumah & Jumlah anggota rumah tangga \\
\hline
\end{tabular}

Model analisis regresi linear berganda dilakukan dengan tujuan untuk mengetahui pengaruh faktor sosial dan demografi masyarakat terhadap tingkat kepatuhan masyarakat dalam penerapan protokol kesehatan. Dependent variable dalam penelitian ini adalah skor tingkat kepatuhan masyarakat dalam penerapan protokol kesehatan, sedangkan variabel lainnya (yaitu status reaksi responden menyikapi kondisi wabah Covid-19, persepsi keefektifan tindakan isolasi diri atau 
karantina mandiri yang dilakukannya dapat memperlambat penyebaran Covid-19, tingkat kekhawatiran tentang berita Covid-19, tingkat kekhawatiran ketika bepergian ke luar rumah, jenis kelamin, tingkat pendidikan, status pernikahan, status kesehatan, usia, status bekerja, dan jumlah anggota rumah) merupakan independent variable.

Model persamaan regresi yang digunakan adalah sebagai berikut:

$$
Y=\alpha+\beta_{1} X_{1}+\beta_{2} X_{2}+\beta_{3} X_{3}+\beta_{4} X_{4}+\beta_{5} X_{6}+\beta_{7} X_{7}+\beta_{8} X_{8}+\beta_{9} X_{9}+\beta_{10} X_{10}+\beta_{11} X_{11}
$$

dimana:

$\mathrm{Y}=$ skor tingkat kepatuhan masyarakat dalam penerapan protokol kesehatan

$\alpha \quad=$ konstanta

$\beta_{1}, \ldots, \beta_{11}=$ koefisien regresi

$X_{1} \quad=$ status reaksi responden menyikapi kondisi wabah Covid-19

$X_{2} \quad=$ persepsi keefektifan tindakan isolasi diri atau karantina mandiri yang dilakukannya dapat memperlambat penyebaran Covid-19

$X_{3} \quad=$ tingkat kekhawatiran tentang berita Covid-19

$X_{4} \quad=$ tingkat kekhawatiran ketika bepergian ke luar $X_{2}=$ rumah

$X_{5} \quad=$ jenis kelamin

$X_{6} \quad=$ tingkat pendidikan

$X_{7} \quad=$ status pernikahan

$X_{8} \quad=$ status kesehatan

$X_{9} \quad=$ usia

$X_{10} \quad=$ status bekerja

$X_{11} \quad=$ jumlah anggota rumah

\section{HASIL DAN PEMBAHASAN}

\section{Kondisi Tingkat Kepatuhan Masyarakat dalam Penerapan Protokol Kesehatan}

.Hasil empiris menunjukkan secara rata-rata indeks kepatuhan responden terhadap penerapan protokol kesehatan mencapai 7,74. Bila dilihat berdasarkan jenis kelamin, ternyata responden lakilaki mempunyai skor tingkat kepatuhan yang relatif lebih rendah dibandingkan responden perempuan yaitu 7,47 berbanding 8,01 . Hal ini menunjukkan bahwa responden perempuan lebih patuh dalam menerapkan protokol kesehatan dalam upaya untuk melindungi dirinya sendiri dari paparan virus Covid-19 dan pencegahan penyebaran Covid-19. Selain itu, jika dilihat berdasarkan kelompok usia, terdapat kecenderungan bahwa kaum muda lebih tidak acuh terhadap penerapan protokol kesehatan. Responden muda mempunyai rata-rata indeks kepatuhan yang relatif rendah dibandingkan dengan kaum yang lebih tua. Rata-rata skor tingkat kepatuhan responden yang berumur di atas usia 50 tahun terhadap penerapan protokol kesehatan melebihi nilai 8. Sebagaimana telah diketahui bahwa penduduk dengan umur di atas 50 tahun menjadi penduduk yang termasuk kategori rentan. Responden dengan usia yang lebih tua memiliki tingkat kesehatan yang lebih rentan terserang dan terpapar virus Covid-19, sehingga mereka akan lebih patuh menerapkan protokol kesehatan dalam kehidupan sehari-harinya.

Bila dilihat berdasarkan status perkawinan, ternyata responden yang hidup sendiri tanpa pasangan baik itu masih berstatus belum menikah mempunyai skor tingkat kepatuhan yang relatif lebih rendah dibandingkan responden yang hidup dengan memiliki pasangan atau berstatus menikah yaitu 7,48 berbanding 7,82 . Hal ini kemungkinan disebabkan responden yang telah mempunyai pasangan tidak ingin terpapar Covid-19 dan menularkannya ke pasangannya. Mereka menjaga diri dan pasangannya dengan tetap terus menerapkan protokol kesehatan dalam kehidupannya. Sementara itu, skor kepatuhan protokol kesehatan pada responden yang berstatus cerai hidup sebesar 7,97 dan cerai mati sebesar 8,21. Hal ini lebih tinggi dibandingkan dengan responden yang berstatus belum menikah dan menikah. Ini dimungkinkan karena sebagian besar responden yang berstatus cerai berada pada kelompok umur yang rentan yaitu katageori sudah berumur lebih tua yang memiliki tingkat kesehatan yang relatif tidak sebaik responden yang lebih muda. Selanjutnya, berdasarkan tingkat pendidikan yang ditamatkan, secara umum dapat dikatakan bahwa semakin 
tinggi jenjang pendidikan yang ditamatkan seseorang, maka akan mempunyai pengetahuan informasi mengenai Covid-19 dan mempunyai kesadaran yang tinggi mengenai begitu pentingnya menjaga diri dari penularan Covid-19. Oleh karena itu, akan semakin tinggi pula skor tingkat kepatuhan penerapan protokol kesehatan dalam kehidupan sehari-harinya.

Tabel 2. Rata-Rata Skor Tingkat Kepatuhan Masyarakat terhadap Protokol Kesehatan.

\begin{tabular}{|c|c|c|c|}
\hline \multirow[t]{2}{*}{ Kategori } & \multicolumn{3}{|c|}{ Jenis Kelamin } \\
\hline & Laki-laki & Perempuan & Total \\
\hline Total & 7,47 & 8,01 & 7,74 \\
\hline \multicolumn{4}{|l|}{ Kelompok Umur } \\
\hline$<=20$ & 6,90 & 7,55 & 7,33 \\
\hline $21-25$ & 7,02 & 7,67 & 7,44 \\
\hline $26-30$ & 7,22 & 7,88 & 7,59 \\
\hline $31-35$ & 7,40 & 8,02 & 7,71 \\
\hline $36-40$ & 7,46 & 8,17 & 7,79 \\
\hline $41-45$ & 7,64 & 8,27 & 7,92 \\
\hline $46-50$ & 7,75 & 8,34 & 7,99 \\
\hline $51-55$ & 7,85 & 8,40 & 8,07 \\
\hline $56-60$ & 7,84 & 8,47 & 8,07 \\
\hline $61-65$ & 7,85 & 8,54 & 8,09 \\
\hline $66+$ & 8,00 & 8,46 & 8,13 \\
\hline \multicolumn{4}{|c|}{ Status Perkawinan } \\
\hline Belum menikah & 7,10 & 7,72 & 7,48 \\
\hline Menikah & 7,56 & 8,14 & 7,82 \\
\hline Cerai mati & 7,76 & 8,32 & 8,21 \\
\hline Cerai hidup & 7,34 & 8,18 & 7,97 \\
\hline \multicolumn{4}{|c|}{ Pendidikan Tertinggi yang Ditamatkan } \\
\hline SD & 6,79 & 7,39 & 7,04 \\
\hline SMP & 7,04 & 7,65 & 7,39 \\
\hline SMA/SMK & 7,31 & 7,89 & 7,59 \\
\hline DI/II/III & 7,53 & 8,13 & 7,86 \\
\hline DIV & 7,06 & 7,67 & 7,42 \\
\hline S1 & 7,51 & 8,06 & 7,79 \\
\hline S2 & 7,76 & 8,19 & 7,96 \\
\hline S3 & 7,89 & 8,29 & 8,07 \\
\hline
\end{tabular}

Sumber: Survei Sosial Demografi Dampak COVID-19, April 2020 (diolah)

\section{Faktor Sosial Demografi yang Berpengaruh pada Kepatuhan Masyarakat dalam Penerapan Protokol Kesehatan}

Untuk mengetahui faktor sosial demografi yang berpengaruh pada kepatuhan masyarakat dalam penerapan protokol kesehatan, penelitian ini menggunakan model regresi linear berganda. Hasil penelitian menunjukkan bahwa dengan tingkat kepercayaan 95 persen, seluruh variabel bebas secara bersama-sama berpengaruh secara signifikan terhadap skor tingkat kepatuhan masyarakat dalam penerapan protokol kesehatan Selain itu, sekitar 10,12 persen variasi dari tingkat kepatuhan masyarakat dalam penerapan protokol kesehatan mampu dijelaskan oleh variasi dari variabel bebasnya, sedangkan sisanya sekitar 89,88 persen dijelaskan oleh variabel lain di luar model persamaan tersebut. Sementara itu, dari hasil uji parsial masing-masing variabel bebasnya diperoleh hasil bahwa dari variabel variabel status reaksi responden menyikapi kondisi wabah Covid-19, persepsi keefektifan tindakan isolasi diri atau karantina mandiri yang dilakukannya dapat memperlambat penyebaran Covid-19, tingkat kekhawatiran tentang berita Covid-19, tingkat kekhawatiran ketika bepergian ke luar rumah, jenis kelamin responden, tingkat pendidikan responden, status pernikahan responden, status kesehatan responden, dan usia responden signifikan memengaruhi tingkat kepatuhan masyarakat dalam penerapan protokol kesehatan pada tingkat signifikansi sebesar 1 persen. Sementara itu, status bekerja dan jumlah anggota rumah tidak signifikan memengaruhi tingkat kepatuhan masyarakat dalam penerapan protokol kesehatan. 
Variabel variabel status reaksi responden menyikapi kondisi wabah Covid-19 mempunyai pengaruh yang signifikan terhadap tingkat kepatuhan masyarakat dalam penerapan protokol kesehatan dengan arah hubungan yang positif. Koefisien regresi yang diperoleh menunjukkan besaran 0,15; artinya skor tingkat kepatuhan protokol kesehatan pada masyarakat yang memiliki reaksi peduli/berlebihan pada kondisi pandemi Covid-19 lebih tinggi 0,15 dari skor patuhan masyarakat yang tidak/kurang peduli pada kondisi pandemi. Dengan kata lain, masyarakat yang memiliki reaksi dengan kepedulian yang tinggi terhadap kondisi pandemi Covid-19 memiliki kecenderungan selalu taat dan patuh pada penerapan protokol kesehatan.

Variabel persepsi keefektifan tindakan isolasi/arantina mandiri mempunyai pengaruh yang signifikan terhadap tingkat kepatuhan masyarakat dalam penerapan protokol kesehatan dengan arah hubungan yang positif. Koefisien regresi yang diperoleh menunjukkan besaran 0,50; artinya skor tingkat kepatuhan protokol kesehatan pada masyarakat yang memiliki persepsi tindakan isolasi/karantina mandiri yang dilakukannya efektif dapat memperlambat penyebaran Covid-19 lebih tinggi 0,50 daripada skor kepatuhan masyarakat yang menganggap tidak efektif. Dengan kata lain, masyarakat yang memiliki persepsi bahwa tindakan isolasi/karantina mandiri yang dilakukannya efektif dapat memperlambat penyebaran Covid-19 memiliki kecenderungan selalu taat dan patuh pada penerapan protokol kesehatan.

Tabel 3. Hasil Persamaan Regresi Tingkat Kepatuhan Masyarakat dalam Protokol Kesehatan

\begin{tabular}{lcc}
\hline Variabel & \multicolumn{2}{c}{ Kepatuhan Protokol Kesehatan } \\
\cline { 2 - 3 } & Koefisien & Standard Error \\
\hline Reaksi & 0,1456 & $0,0100^{* * *}$ \\
\hline Efektif & 0,4967 & $0,0136^{* * *}$ \\
\hline Berita_khawatir & 0,1708 & $0,1212^{* * *}$ \\
\hline Pergi_khawatir & 0,3477 & $0,0206^{* * *}$ \\
\hline Status_bekerja & 0,0177 & 0,0119 \\
\hline Jenis_kelamin & $-0,5920$ & $0,0100^{* * *}$ \\
\hline Ijasah & 0,2713 & $0,0423^{* * *}$ \\
\hline Status_bersama & 0,1115 & $0,0124^{* * *}$ \\
\hline Status_kesehatan & 0,4344 & $0,0234^{* * *}$ \\
\hline Usia & 0,0202 & $0,0005^{* * *}$ \\
\hline Jumlah_ART & $-0,0040$ & $-0,0026$ \\
\hline Konstanta & 5,5762 & $0,0567^{* * *}$ \\
\hline
\end{tabular}

Sumber: Survei Sosial Demografi Dampak COVID-19, April 2020 (diolah dengan STATA 14.0)

Variabel tingkat kekhawatiran tentang berita Covid-19 mempunyai pengaruh yang signifikan terhadap tingkat kepatuhan masyarakat dalam penerapan protokol kesehatan dengan arah hubungan yang positif. Koefisien regresi yang diperoleh menunjukkan besaran 0,17 ; artinya skor tingkat kepatuhan protokol kesehatan pada masyarakat yang khawatir tentang pemberitaan Covid19 lebih tinggi 0,50 daripada skor kepatuhan masyarakat yang tidak/kurang khawatir. Dengan kata lain, masyarakat yang memiliki kekhawatiran yang tinggi akan adanya pemberitaan Covid-19 mempunyai kecenderungan untuk selalu taat dan patuh pada penerapan protokol kesehatan.

Variabel tingkat kekhawatiran saat bepergian ke luar rumah mempunyai pengaruh yang signifikan terhadap tingkat kepatuhan masyarakat dalam penerapan protokol kesehatan dengan arah hubungan yang positif. Koefisien regresi yang diperoleh menunjukkan besaran 0,35; artinya skor tingkat kepatuhan protokol kesehatan pada masyarakat yang khawatir saat bepergian ke luar rumah lebih tinggi 0,35 daripada skor kepatuhan masyarakat yang tidak/kurang khawatir saat bepergian ke luar rumah. Dengan kata lain, masyarakat yang memiliki kekhawatiran yang tinggi saat bepergian ke luar rumah mempunyai kecenderungan untuk selalu taat dan patuh pada penerapan protokol kesehatan. Hal ini mengingat masih tingginya penularan Covid-19 saat berada di luar rumah jika tidak melakukan protokol kesehatan.

Variabel jenis kelamin ternyata menunjukkan adanya pengaruh yang signifikan terhadap tingkat kepatuhan masyarakat dalam penerapan protokol kesehatan dengan arah hubungan yang negatif. Koefisien regresi yang diperoleh menunjukkan besaran $-0,59$; artinya skor tingkat kepatuhan 
protokol kesehatan pada responden laki-laki lebih rendah 0,59 dari skor kepatuhan perempuan. Dengan kata lain, perempuan memiliki kecenderungan akan selalu taat dan patuh pada penerapan protokol kesehatan dibandingkan laki-laki.

Variabel ijazah/tingkat pendidikan tertinggi yang ditamatkan berpengaruh signifikan terhadap tingkat kepatuhan masyarakat dalam penerapan protokol kesehatan dengan arah hubungan yang positif. Koefisien regresi yang diperoleh menunjukkan besaran 0,27; artinya skor tingkat kepatuhan protokol kesehatan pada responden yang memiliki ijazah SMA ke atas lebih tinggi 0,27 daripada responden yang hanya tamatan SMP ke bawah. Dengan kata lain, seseorang dengan tingkat pendidikan yang lebih tinggi akan memiliki kecenderungan akan selalu taat dan patuh pada penerapan protokol kesehatan mengingat pengetahuan yang dimilikinya terkait bahaya Covid-19 dan informasi mengenai pengendalian penyebaran Covid-19.

Variabel status pernikahan juga mempunyai pengaruh yang signifikan terhadap tingkat kepatuhan masyarakat dalam penerapan protokol kesehatan dengan arah hubungan yang positif. Koefisien regresi yang diperoleh menunjukkan besaran 0,11; artinya skor tingkat kepatuhan protokol kesehatan pada responden yang menikah dan tinggal bersama pasangannya lebih tinggi 0,11 daripada responden yang belum menikah atau sudah cerai. Dengan kata lain, seseorang yang hidup bersama dengan pasagannya akan memiliki kecenderungan akan selalu taat dan patuh pada penerapan protokol. Hal ini disebabkan mereka tidak ingin terkena paparan virus Covid-19 dan menularkannya kepada pasangannya.

Selanjutnya, variabel status kesehatan ternyata mempunyai pengaruh positif dan signifikan terhadap tingkat kepatuhan masyarakat dalam penerapan protokol kesehatan. Koefisien regresi yang diperoleh menunjukkan besaran 0,43; artinya skor tingkat kepatuhan protokol kesehatan pada responden yang dalam kondisi sehat lebih tinggi 0,43 daripada responden yang sedang sakit/kurang sehat. Dengan kata lain, seseorang yangs sehat akan selalu menjaga kesehatannya dan memiliki kecenderungan akan selalu taat dan patuh pada penerapan protokol kesehatan agar tidak terpapar Covid-19.

Variabel usia/umur ternyata menunjukkan juga berpengaruh positif dan signifikan terhadap tingkat kepatuhan masyarakat dalam penerapan protokol kesehatan dengan koefisien regresi sebesar 0,02. Artinya semakin tinggi usia responden maka semakin tinggi pula tingkat kepatuhan protokol kesehatan. Dengan kata lain, tingkat kepatuhan masyarakat terhadap penerapan protokol kesehatan lebih banyak ditemukan pada seseorang yang lebih tua/lanjut dibandingkan dari kalangan muda. Hal ini disebabkan pada kalangan tua mempunyai tingkat kerentanan yang tinggi terpapar Covid-19 sehingga seseorang yang masuk ke dalam kategori rentan akan memiliki kecenderungan akan selalu taat dan patuh pada penerapan protokol kesehatan agar tidak terpapar Covid-19.

Variabel status bekerja tidak signifikan berpengaruh terhadap tingkat kepatuhan masyarakat dalam penerapan protokol kesehatan, walaupun mempunyai arah hubungan yang positif. Hal ini ditandai dengan koefisien regresi yang hanya sebesar 0,02; artinya dapat dikatakan tidak ada perbedaan yang berarti antara skor tingkat kepatuhan protokol kesehatan pada masyarakat yang sedang bekerja dan yang tidak bekerja. Namun demikian, dari arah hubungan dapat dikatakan bahwa selama bekerja responden akan cenderung mentaati protokol kesehatan di lingkungan kerja. Setiap lingkungan kerja/kantor telah dihimbau oleh pemerintah agar menerapkan kebijakan selalu melakukan protokol kesehatan dalam segala kegiatan ekonomi di lingkungan kerja yang harus ditaati oleh seluruh pekerja/karyawannya.

Variabel jumlah anggota rumah tangga tidak signifikan berpengaruh terhadap tingkat kepatuhan masyarakat dalam penerapan protokol kesehatan, tetapi mempunyai arah hubungan yang negatif. Hal ini ditandai dengan koefisien regresi yang relatif sangat kecil; artinya dapat dikatakan tidak ada perbedaan yang berarti antara skor tingkat kepatuhan protokol kesehatan pada masyarakat yang mempunyai jumlah anggota rumah tangga yang sedikit atau banyak.

\section{KESIMPULAN}

Kesimpulan yang dapat ditarik dari penelitian ini yaitu rata-rata indeks kepatuhan responden dari kalangan muda dan berjenis kelamin laki-laki dalam penerapan protokol kesehatan dibanding dari kalangan dengan umur lebih tua dan berjenis kelamin perempuan. Di sisi lain, status kesehatan responden mempunyai pengaruh yang cukup tinggi terhadap kepatuhan responden, di mana status 
kesehatannya rendah (kategori rentan yang biasanya dialami penduduk usia lanjut usia) cenderung akan lebih patuh pada protokol kesehatan. Selain itu, hasil empiris juga menunjukkan seseorang yang masih berstatus telah menikah dan mempunyai tingkat pendidikan yang tinggi akan lebih mematuhi penerapan protokol kesehatan.

Beberapa karakteristik sosial, demografi, dan ekonomi dari responden yang berpengaruh pada tingkat kepatuhan terhadap penerapan protokol kesehatan antara lain status reaksi responden menyikapi kondisi wabah Covid-19, persepsi keefektifan tindakan isolasi diri atau karantina mandiri yang dilakukannya dapat memperlambat penyebaran Covid-19, tingkat kekhawatiran tentang berita Covid-19, tingkat kekhawatiran ketika bepergian ke luar rumah, jenis kelamin responden, tingkat pendidikan responden, status pernikahan responden, status kesehatan responden, dan usia responden. Diharapkan masyarakat lebih patuh pada penerapan protokol kesehatan sesuai dengan anjuran dari pemerintah. Selain itu, pemerintah diharapkan lebih intens lagi dalam pengawasan untuk ketertiban perilaku masyarakat dalam mematuhi penerapan prokol kesehatan dalam lingkungannya demi pengendalian penyebaran pandemi Covid-19.

\section{Rekomendasi Penelitian Berikutnya}

Terdapat beberapa rekomendasi yang dapat dilakukan untuk penelitian berikutnya. Pertama, perlu dilakukan analisis dengan mengikutsertakan variabel pemberlakuan kebijakan PSBB pada setiap daerah kabupaten/kota untuk mendapatkan gambaran lebih mendalam mengenai keefektifan kebijakan PSBB. Kedua, perlu memasukkan jumlah korban yang terpapar Covid-19 di dalam model. Ketiga, perlu memasukkan variabel demografi dari sisi psikologi responden di masa pandemi. Keempat, perlu dilakukan kajian analisis lebih mendalam dengan mengeksplor berbagai kajian teori atau literatur baik mengenai pandemi virus Covid-19 maupun virus sejenis di masa lalu sebagai perbandingan.

\section{UCAPAN TERIMA KASIH}

Penulis R dan P.L. mengucapkan terima kasih kepada Kepala Subdirektorat Indikator Statistik yang telah memberikan saran dan masukan terkait penyusunan penelitian ini. Penulis juga mengucapkan terima kasih kepada BPS sebagai penyedia data dalam penelitian ini.

\section{DAFTAR PUSTAKA}

Ajzen, I. (2005). Atttudes, Personality and Behavior. In International Journal of Strategic Innovative Marketing, 3, 117. https://psicoexperimental.files.wordpress.com/2011/03/ajzeni-2005-attitudespersonality-and-behaviour-2nd-ed-open-university-press.pdf

Bashirian, S., Jenabi, E., Khazaei, S., Barati, M., Karimi-Shahanjarini, A., Zareian, S., Rezapur-Shahkolai, F., \& Moeini, B. (2020). Factors associated with preventive behaviours of COVID-19 among hospital staff in Iran in 2020: an application of the Protection Motivation Theory. The Journal of Hospital Infection, 105(3), 430-433. https://doi.org/https://doi.org/10.1016/j.jhin.2020.04.035

BPS. (2020). Hasil Survei Sosial Demografi Dampak COVID-19. BPS.

Greene, W. H. (2012). Econometric Analysis. Prentice Hall.

Gujarati, D., \& Porter, D. (2009). Basic Econometrics (Fifth). McGraw-Hill.

Kemenkes. (2020). Pedoman Pencegahan dan Pengendalian Corona Virus Disease (Covid-19). Kemenkes.

Prasetyo, Y. T., Castillo, A. M., Salonga, L. J., Sia, J. A., \& Seneta, J. A. (2020). Factors affecting perceived effectiveness of COVID-19 prevention measures among Filipinos during Enhanced Community Quarantine in Luzon, Philippines: Integrating Protection Motivation Theory and extended Theory of Planned Behavior. International Journal of Infectious Diseases, 99, 312-323. https://doi.org/https://doi.org/10.1016/j.ijid.2020.07.074

Raude, J., Lecrique, J.-M., Lasbeur, L., Leon, C., Guignard, R., du Roscoät, E., \& Arwidson, P. (2020). Determinants of preventive behaviors in response to the COVID-19 pandemic in France: comparing the sociocultural, psychosocial and social cognitive explanations. https://doi.org/https://doi.org/10.31234/osf.io/4yvk2

Rogers, R. W., \& Prentice-Dunn, S. (1997). Protection motivation theory. In Handbook of health behavior research 1: Personal and social determinants (D. S. Goch) (D. S. Goch). Plenum Press. 
Triyanto, E., \& Kusumawardani, L. H. (2020). Analysis of Change Behavior Prevention of Covid-19 Transmission Based on Integrated Behavior Model. Jurnal Keperawatan Soedirman, 15(2), 66-73. https://doi.org/http://dx.doi.org/10.20884/1.jks.2020.15.2.1441

Yanti, B., Mulyadi, E., Wahiduddin, Novika, R. G. H., Arina, Y. M. D., Martani, N. S., \& Nawan. (2020). Community Knowledge, Attitudes, And Behavior Towards Social Distancing Policy As A Means Of Preventing Transmission Of Covid-19 In Indonesia. Jurnal Administrasi Kesehatan Indonesia, 8(1), 414. https://doi.org/http://dx.doi.org/10.20473/jaki.v8i2.2020.4-14 